\author{
Associate Professor Mircea Constantin DUICA, PhD \\ E-mail: mircea_duica@yahoo.com \\ Lecturer Nicoleta Valentina FLOREA, PhD \\ E-mail: floreanicol@yahoo.com \\ Associate Professor Anisoara DUICA, PhD \\ E-mail: anisoara_duica@yahoo.com \\ Raluca GILMEANU, PhD Student \\ E-mail: raluman72@yahoo.com \\ Valahia University of Targoviste
}

\title{
IMPROVING THE RELATIONSHIPS BETWEEN ORGANIZATIONS AND THEIR CUSTOMERS USING DIGITAL MULTICHANNEL COMMUNICATION AND MATHEMATICAL SIMULATION
}

\begin{abstract}
We are living in the age of relationship marketing and relationships with customers are the central point of any business. And because a business cannot survive without its customers, in this article we will present their importance for organization and the new channels used to maintain a long-term relationship-effective digital multichannel, such as website, email, social media marketing channels or mobile apps, used to attract and satisfy the present and the potential customers' needs. We also will present the advantages and the new opportunities offered for customers but also for organization using new technologies. Using data from worldwide level we will develop a model using IT and mathematical programs such as EViews, MATLAB, regression function, and Markov chains to observe the relationship between the analyzed variables and the future trends of these multichannel used in online communication.
\end{abstract}

Keywords: Markov chains, mathematical simulation, online business, social networking platforms, digital multichannel communication.

JEL classification:C15, D83, M15

DOI: 10.24818/18423264/53.1.19.17 
Mircea Constantin Duica, Nicoleta Valentina Florea, Anisoara Duica, Raluca Gilmeanu

\section{Introduction}

Consumers want always to obtain value, no matter what and from where they are buying. And no matter how good their needs are satisfied; the consumers expectations will accelerate. Global communication was helped by the technology advancement, such as Internet, Intranet, e-mail, fax and mobile phones Technology is a major factor who is influencing any field and is leading to globalization development, especially in communication. Communication is probably the most central process in organizations (Floreaand Gilmeanu, 2016), thus this process has become important even for the small enterprises who also has global ambitions, facilitating them the collaboration with large enterprises or with the costumers from different zones (Lowell and Joyce, 2007), and relationships are created attracting and retaining customers and using two-ways conversations in order to create value (Gothelf and Seiden, 2017).The simulation and modeling techniques helped organizations to improve their future performance and predict future risks into the future (is not trying to replace the classical communication but to complete it), in a world of online business, online communication which is the backbone of all the organization' processes.

\section{About the needs of customers and the new technologies}

The needs of customers are continue to evolve, and to satisfy them the marketers must know them and understand them (Natarajan, 2017), must identify proactive methods to fulfill their needs and expectations, must monitored them, analyze the degree of satisfaction and to improve their product/service to offer them value, to credibility, trust and long term relationship. The challenge for any organization is satisfaction of customer's needs.

The customers ways of buying are changing; they are buying now faster, cheaper and better using Internet and new social media tools: website, email, social media marketing channels or mobile apps (Table 1). Any change is not accepted easily, comfortably, or readily (Albright, 2018), thus the penetration rate of Internet was $46.1 \%$ in 2016 , but continue to raise (98\% in Norway, Romania 58\%, and Eritrea $1.1 \%$ ) (www.internetlivestats.com/internet-users-by-country/).

Table 1. The use of Internet and social media websites in the world (20162017)(million)

\begin{tabular}{|c|c|c|c|c|c|c|}
\hline $\begin{array}{l}\text { Total } \\
\text { world }\end{array}$ & $\begin{array}{c}\text { Internet } \\
\text { users (31 } \\
\text { March } \\
\text { 2017) }\end{array}$ & $\begin{array}{c}\text { Facebook } \\
\text { (01 Feb } \\
\text { 2017) }\end{array}$ & $\begin{array}{c}\text { Twitter } \\
\text { (01 Feb } \\
\text { 2016) }\end{array}$ & $\begin{array}{c}\text { LinkedIn } \\
\text { (01 Feb } \\
2016)\end{array}$ & $\begin{array}{c}\text { Pinterest } \\
\text { (01 Feb } \\
\text { 2016) }\end{array}$ & $\begin{array}{c}\text { Google } \\
\text { plus }(01 \\
\text { Feb } \\
\text { 2016) }\end{array}$ \\
\hline $7,519.029$ & $3,696.240$ & $1,800.000$ & 310.000 & 255.000 & 250.000 & 120.000 \\
\hline
\end{tabular}

Source:www.internetworldstats.com 
Improving the Relationships between Organizations and their Customers Using Digital Multichannel Communication and Mathematical Simulation

Internet has a unique characteristic: that of being available for anybody (Baran and Davis, 2012), of finding new data and information, of transmitting messages, of connecting to the markets, and of becoming more flexible and powerful every day (Thomas, 2007).Internet tends to grow in being a tool necessary for global communication. Internet, the new direct marketing tool, has led to sales growing through online orders. Due to its rapid global development, the Internet has become one of the most important media means that we can ever imagine.

As we may observe, the Internet has changed the way of shopping, offering fast information transfer and reduced costs, of interaction (Neustaldter et al., 2012) $24 / 7 / 365$, development opportunities and the new social media tools offer a new opportunity to communicate, to relate, to collaborate, to make business, to entertain or to shop.

\section{The websites}

External communication with customers may be formal or informal; one of the tools used in this relationship are websites (Krizan et al, 2011) and in general are used by managers and organizations to find out the customers' needs or to collect information necessary to make decisions.

As we may see below, the customers' expectations are continuously evolving, and they are satisfied if the social media websites offer them convenience, personalization, speed, efficiency, empowerment, seamlessness, ease, authenticity and affirmation. Making a comparison, we may see the differences between these characteristics in the past and in the present (Table 2).

Table 2. Customer expectation trends

\begin{tabular}{|l|l|l|}
\hline & Then & Now \\
\hline Convenience & One-click & Dash buttons \\
\hline Personalization & Perfect the customer journey & Optimize micro-moments \\
\hline Speed & Overnight shipping & Same-day satisfaction \\
\hline Efficiency & Hunt and peck & Voice recognition \\
\hline Empowerment & Customer reviews & Response to comments \\
\hline Seamlessness & Wearables and Apps & Nearables \\
\hline Ease & PayPal & Apple Pay \\
\hline Authenticity & Solid history & True transparency \\
\hline Affirmation & Feeling of cool & Feeling of meaning \\
\hline
\end{tabular}

Source:www.forbes.com 
Mircea Constantin Duica, Nicoleta Valentina Florea, Anisoara Duica, Raluca Gilmeanu

The first website was developed in 1991 by the British physicist Tim Berners-Lee at CERN, in Switzerland. There are 1.2 billion websites on the world wide web in 2017. The website development continues from 1 website in 1991 to 1 billion in 2014. The trend of website evolution is seen below (Table 3).

Table 3.The total number of websites in the world (2000-2015) (million)

\begin{tabular}{|c|c|c|c|c|c|c|c|c|}
\hline Year & $\mathbf{2 0 0 1}$ & $\mathbf{2 0 0 5}$ & $\mathbf{2 0 0 7}$ & $\mathbf{2 0 0 9}$ & $\mathbf{2 0 1 1}$ & $\mathbf{2 0 1 3}$ & $\mathbf{2 0 1 5}$ & $\mathbf{2 0 1 7}$ \\
\hline $\begin{array}{c}\text { Websites } \\
\text { number }\end{array}$ & 29.25 & 64.78 & 121.89 & 238.02 & 346.00 & 672.98 & 863.10 & 1002.00 \\
\cline { 3 - 7 } & & & & & & & &
\end{tabular}

Source:www.internetlivestats.com/total-number-of-websites/

When it comes to a great website experience, internet users consider performance more important than fresh content, consistent experiences across mobile and desktop, and personalized content, finds Limelight Networks in a study entitled "The State of the User Experience". For example, roughly 1 in 5 respondents aren't willing to wait longer than 3 seconds for a website to load before getting frustrated and leaving (http://trends.e-startegyblog.com/2016/).

\section{Social networking platforms}

A national survey of 1,520 adults conducted by the PewResearchCenter between March 7-April 4, 2016, finds that Facebook continues to be America's most popular social networking platform and three-quarters (76\% - of Facebook users report that they visit the site daily)and Twitter, Instagram, Pinterest and LinkedIn knew a significant increase over the past years(Figure 1).

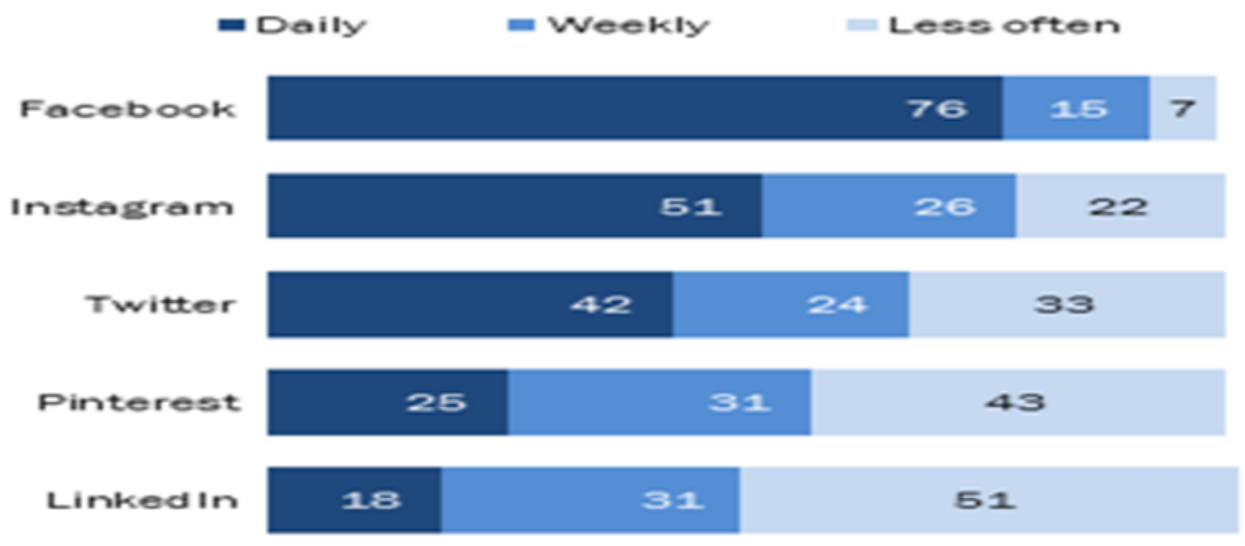

Figure 1. Use of social media tools

Source:http://trends.e-strategyblog.com/2016/12/03/frequency-social-media-usenetwork/27841 
Improving the Relationships between Organizations and their Customers Using Digital Multichannel Communication and Mathematical Simulation

\section{Mobile apps}

Now, the customers want to have many activities online, for their advantages, but, especially on the move. Thus, mobile tools have become important in their daily lives. A survey made in 2016 on 4,500 Internet users worldwide with over 18 years old showed the expectations for mobile experience (Figure 2).

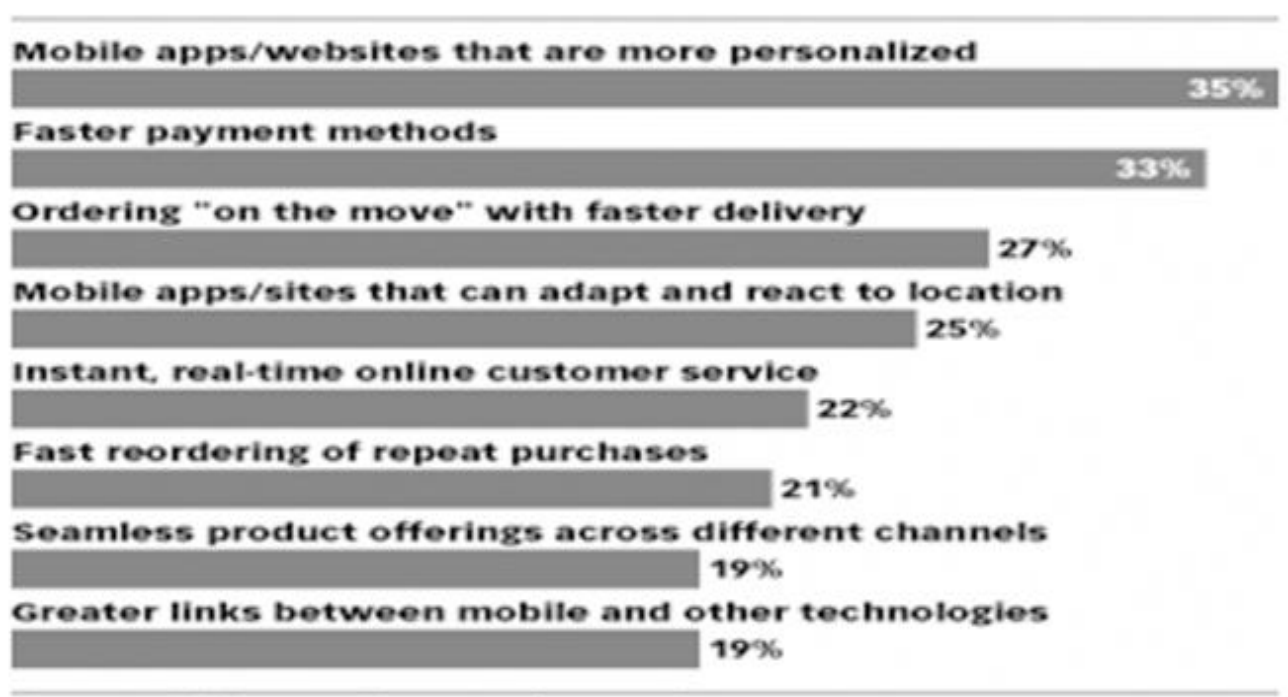

Figure 2. Future expectations for the mobile experience Source:http://trends.e-strategyblog.com/2016/07/28/mobile-experienceexpectations $/ 27361$

We may observe that the internet users want more personalized apps $(35 \%)$, a faster way to pay (33\%), to deliver (27\%), adaptation $(25 \%)$, and so on. Another survey, also made in 2016 (among 4,500 mobile-owning adults across 11 countries), showed that convenience (48\%), security (46\%) and speed $(42 \%)$ are the most important elements of a good mobile experience (Figure 3). 
Mircea Constantin Duica, Nicoleta Valentina Florea, Anisoara Duica, Raluca Gilmeanu

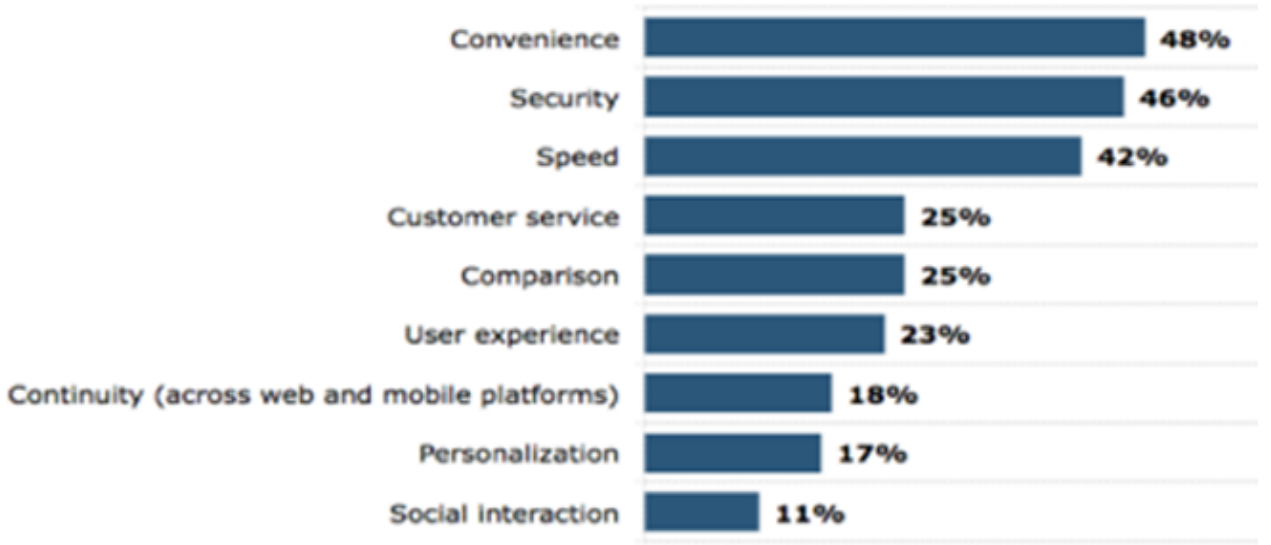

Figure 3. The most important elements of a good mobile experience

\section{Source:http://trends.e-strategyblog.com/2016/10/24/top-elements-good-mobile- experience $/ 27676$}

\section{E-mail}

With the emergence of communication on Internet, a new form of communication has developed- e-mail communication that involves information exchange and depends on who uses it, the program used, the time of transmission / receipt and the answers given (Janoschka, 2004).

To efficiently transmit an e-mail, it is needed to know the address, to establish a subject, to mention the motive of writing it, to read it before transition, in order to avoid the errors and to use the introduction and the ending formulation (Jain et al., 2011).

E-mail is more and more used in daily communication of individuals and of organizations. The top ten used email position ns are:1.Apple iPhone: 33.0\%, 2.Gmail: $15.8 \%$, 3.Apple iPad: 11.6\%, 4.Android: 10.3\%, 5.Apple Mail: 6.6\%, 6.Outlook: 6.7\%, 7.Yahoo! Mail: 3.0\%, 8.Outlook.com: 2.1\%, 9.Windows Live Mail: $1.3 \%, 10$. Thunderbird: $0.7 \%$ (www.litmus.com).

To see that email has become a very important part of our lifes personal and professional, we offer some statistics:

- $\quad$ in January 2017 the number of emails sent daily was 269 billions emails;

- the number of e-mail users worldwide was in 2017 of 3.718 billion (https://www.radicati.com/wp/wp-content/uploads/2017/01/Email-

Statistics-Report-2017-2021-Executive-Summary.pdf);

- Consumers have in 2017 an average of 1.7 accounts per user and in the next four years will continue to grow till 1.86 accounts per user (https://www.radicati.com/wp/wp-content/uploads/2017/01/EmailStatistics-Report-2017-2021-Executive-Summary.pdf); 
Improving the Relationships between Organizations and their Customers Using Digital Multichannel Communication and Mathematical Simulation

- in 2016 the greatest number of emails were opened on mobile devices at $54 \%$, Webmail ranked second at $30 \%$ and Desktop email opens dropped to 16\%. (www.litmus.com/2016);

- people check e-mail while watching TV or while watching a movie (69 percent), in bed (57 percent), and on vacation (79percent) (www.adobe.com/2016);

- a percent of $67,2 \%$ of consumers use a smartphone to check their e-mail, $42,3 \%$ use a tablet while $93,3 \%$ uses desktop environment (www.bluehornet.com/.../2015-Consumer-Views-of-Email-Marketing$\underline{2015}$.

Also, sending and receiving so much emails, and to avoid the risk of overloading, organizations implemented effective programs in order to budget the employees' time (consisting in sorting or redirecting emails or reducing the time to work with them- creating a day of „e-mail free”) (Hynes andVeltsos, 2018).

\section{Research methodology}

Our research has two objectives:

1.to observe the relationships between Internet users and the users of new media channels using IT simulation and mathematical modeling- EViews program and regression function,

2.to improve the website experience using simulation- MATLAB and Markov chains,

3. to observe the trend of different social media tools also applicating a simulation method based on Markov chains.

7.1.Analysing the relationships between analysed variables using data from world level between 2009-2017

In this research we used data regarding the use of social media worldwide (Table 4) influenced by the use of the Internet. Due to the fact that Internet inceased its users numbers, and the interest in using social media platforms has also increased, we consider as important the relationship between these variables. We want to determine if there is a relationship between these variables and how strong it is. 
Mircea Constantin Duica, Nicoleta Valentina Florea, Anisoara Duica, Raluca Gilmeanu

Table 4. Data regarding the analysed variables

\begin{tabular}{|c|c|c|c|c|c|}
\hline Year & $\begin{array}{l}\text { World Internet } \\
\text { users (million) } \\
\text { (www.internetl } \\
\text { ivestats.com) }\end{array}$ & 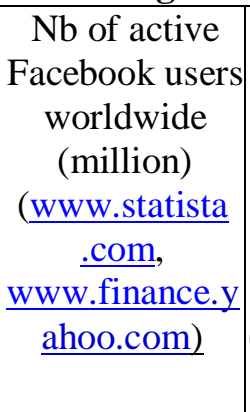 & $\begin{array}{c}\text { Nb of } \\
\text { monthly } \\
\text { active Twitter } \\
\text { users } \\
\text { worldwide } \\
\text { first quarter } \\
\text { (million) } \\
\text { (www.statista } \\
\text {.com) }\end{array}$ & $\begin{array}{c}\text { Nb of } \\
\text { email } \\
\text { users } \\
\text { worldwide } \\
\text { (million) } \\
\text { (www.radi } \\
\underline{\text { cati.com) }}\end{array}$ & $\begin{array}{c}\begin{array}{c}\text { Nb. of } \\
\text { websites }\end{array} \\
\text { worldwide } \\
\text { (million) } \\
\text { (www.inter } \\
\text { netlivestatis } \\
\underline{\text {.com) }}\end{array}$ \\
\hline 2009 & 1,766 & 350 & 20 & 2,192 & 238 \\
\hline 2010 & 2,023 & 608 & 30 & 2,200 & 206 \\
\hline 2011 & 2,231 & 845 & 68 & 2,350 & 346 \\
\hline 2012 & 2,494 & 1,010 & 138 & 2,370 & 697 \\
\hline 2013 & 2,728 & 1,228 & 204 & 2,400 & 672 \\
\hline 2014 & 2,956 & 1,393 & 255 & 2,500 & 968 \\
\hline 2015 & 3,185 & 1,591 & 302 & 2,586 & 863 \\
\hline 2016 & 3,424 & 1,860 & 310 & 2,672 & 966 \\
\hline 2017 & 3,655 & 1,940 & 328 & 2,760 & 1,206 \\
\hline
\end{tabular}

Source: www.internetlivestats.com, www.statista.com, www.radicati.com, https://finance.yahoo.com/

To see such a relationship, we can use the function of multiple regression which is a method of studying the evolution of a dynamic system starting from the successive observations of some characteristics of the system (Floreaand Mihai, 2015).

Using regression function and EViews7 program we analyse if there is a relationship between the analysed variables and its strength on 9 years.

We consider as dependent variable: World Internet users and as independent variables: $\mathrm{Nb}$ of active Facebook users, $\mathrm{Nb}$ of monthly active Twitter users, $\mathrm{Nb}$ of email users and $\mathrm{Nb}$. of websites.

Using Least squares method (OLS) (Table 5), we may observe that Rsquared is $99.08 \%$, being a very strong and positive relationship between the analyzed variables. 
Improving the Relationships between Organizations and their Customers Using Digital Multichannel Communication and Mathematical Simulation

Table 5. Least squares method

\begin{tabular}{|c|c|c|c|c|}
\hline \multicolumn{4}{|c|}{ Dependent Variable: WORLD_INTERNET_USERS__MI } & \\
\hline \multicolumn{4}{|c|}{ Method: Least Squares } & \\
\hline \multicolumn{5}{|l|}{ Included observations: 9} \\
\hline $\begin{array}{r}\text { Variable } \\
\end{array}$ & Coefficient & Std. Error & t-Statistic & Prob. \\
\hline NB_OF_MONTHLY_ACTIVE_TWI & 0.003154 & 0.001672 & 1.886726 & 0.1322 \\
\hline NB_OF_EMAIL_USERS_WORLDW & 1.405752 & 0.845314 & 1.662995 & 0.1716 \\
\hline NB_OF_ACTIVE_FACEBOOK_US & $3.62 \mathrm{E}-05$ & 0.000193 & 0.187906 & 0.8601 \\
\hline NB_OF_WEBSITES_WORLDWID & $-8.32 \mathrm{E}-05$ & 0.000127 & -0.653973 & 0.5488 \\
\hline \begin{tabular}{|c|}
$\mathrm{C}$ \\
\end{tabular} & -1.264469 & 1.794587 & -0.704602 & 0.5199 \\
\hline R-squared & 0.990832 & \multicolumn{2}{|c|}{ Mean dependent var } & 2.718000 \\
\hline Adjusted R-squared & 0.981663 & \multicolumn{2}{|c|}{ S.D. dependent var } & 0.644972 \\
\hline S.E. of regression & 0.087338 & \multicolumn{2}{|c|}{ Akaike info criterion } & -1.737886 \\
\hline Sum squared resid & 0.030512 & \multicolumn{2}{|c|}{ Schwarz criterion } & -1.628316 \\
\hline Log likelihood & 12.82048 & \multicolumn{2}{|c|}{ Hannan-Quinn criter. } & -1.974336 \\
\hline F-statistic & 108.0705 & \multicolumn{2}{|c|}{ Durbin-Watson stat } & 2.521807 \\
\hline Prob(F-statistic) & 0.000251 & & & \\
\hline
\end{tabular}

Source: Calculation made by the authors using EViews7

Using EViews is obtained the following regression function:

$Y=0.003 * x 1+1.4 * x 2+3.6 * x 3-8.3 * x 4-1.26(1)$

From the formula founded by EViews7 results that the chosen independent variables are very important factors in the evolution of dependent variable.

Table 6. Correlation between variables

\begin{tabular}{|c|c|c|c|c|c|}
\hline Variables & $\begin{array}{c}\text { WORLD_INTE } \\
\text { RNET_USERS } \\
\text { _MI }\end{array}$ & $\begin{array}{c}\text { NB_OF_MONT } \\
\text { HLY_ACTIVE_ } \\
\text { TWI }\end{array}$ & $\begin{array}{l}\text { NB_OF_EMA } \\
\text { IL_USERS_- } \\
\text { WORLDW }\end{array}$ & $\begin{array}{l}\text { NB_OF_AC } \\
\text { TIVE_FACE } \\
\text { BOOK_US }\end{array}$ & $\begin{array}{c}\text { NB_OF_WEBS } \\
\text { ITES_WORLD } \\
\text { WID }\end{array}$ \\
\hline $\begin{array}{c}\text { WORLD_INTERNET_U } \\
\text { SERS_MI }\end{array}$ & 1 & & & & \\
\hline $\begin{array}{c}\text { NB_OF_MONTHLY_A } \\
\text { CTIVE_TWI }\end{array}$ & 0.98 & 1 & & & \\
\hline $\begin{array}{c}\text { NB_OF_EMAIL_USER } \\
\text { S_WORLDW }\end{array}$ & 0.98 & 0.95 & 1 & & \\
\hline $\begin{array}{c}\text { NB_OF_ACTIVE_FACE } \\
\text { BOOK_US }\end{array}$ & -0.69 & -0.77 & -0.62 & 1 & \\
\hline $\begin{array}{c}\text { NB_OF_WEBSITES_W } \\
\text { ORLDWID }\end{array}$ & 0.33 & 0.45 & 0.27 & -0.52 & 1 \\
\hline
\end{tabular}

Source: Calculation made by the authors using EViews 7 
Mircea Constantin Duica, Nicoleta Valentina Florea, Anisoara Duica, Raluca Gilmeanu

The values obtained in the table above (Table 6) shows the strength of the relationship between the variables:

- If the value is 0- the two variables are not related to each other at all. In this category there is no correlation.

- If the value is between ( 0 and 1)- the relationship becomes stronger and stronger, and if it is closer to one, means that the two variables are very strongly related to each other. In this category there are three correlations, as follows: the strongest correlation is between y and $\mathrm{x} 1$ and $\mathrm{x} 2(0.98)$ being very close to 1 , between $\mathrm{x} 1$ and $\mathrm{x} 2(0.95)$. Wicker relationships are between $\mathrm{x} 1$ and $\mathrm{x} 4(0.45), \mathrm{y}$ and $\mathrm{x} 4(0.33)$ and the wickest but positive is between $\mathrm{x} 2$ and $\mathrm{x} 4$ (0.27).

- If the value is between ( 0 and -1)- is a low correlation and the two variables are a little bit related to each other, or not at all. Here there are correlations, as follows: $\mathrm{x} 3$ and $\mathrm{x} 4(-0.52), \mathrm{x} 2$ and $\mathrm{x} 3(-0.62)$, $\mathrm{y}$ and $\mathrm{x} 3(-0.69)$ and lower value is obtained for $\mathrm{x} 1$ and $\times 3(-0.77)$.

As a final conclusion, we may add that $\mathrm{Y}$ (Internet users) is influencing the number of Twitter users and the email users in the world. Facebook, as we may see is not influenced only by the ability to use Internet, but from other different reasons, too: age, sex, gender (female use more then male), comments received, life events, health, marrital status, job, geographical area, and so on.

\subsection{Improving a website experience}

We used data from a survey made in 2015 and 2016 (Table 7) and using simulation- Markov chains we want to see the trends for the analysed characteristics for the next years.

Table 7. Internet users expectations from a website experience (\%)

\begin{tabular}{|c|c|c|c|c|c|c|}
\hline Expectations & Year & $\begin{array}{c}4 \\
\text { (most } \\
\text { important) }\end{array}$ & 3 & 2 & $\begin{array}{c}1 \\
\text { (least } \\
\text { important) }\end{array}$ & $\begin{array}{l}\text { The } \\
\text { score }\end{array}$ \\
\hline \multirow[t]{2}{*}{ Performance } & 2015 & 52 & 26 & 9 & 13 & 3.17 \\
\hline & 2016 & 50.2 & 27.1 & 14.2 & 8.5 & 3.19 \\
\hline \multirow[t]{2}{*}{$\begin{array}{l}\text { Fresh and updated } \\
\text { content }\end{array}$} & 2015 & 39 & 29 & 19 & 13 & 2.94 \\
\hline & 2016 & 43.4 & 28.4 & 19.5 & 8.7 & 3.06 \\
\hline \multirow[t]{2}{*}{ Consistent experience } & 2015 & 20 & 27 & 35 & 18 & 2.49 \\
\hline & 2016 & 23.5 & 27.7 & 32.3 & 16.5 & 2.582 \\
\hline \multirow[t]{2}{*}{ Personalized content } & 2015 & 12 & 18 & 26 & 44 & 1.98 \\
\hline & 2016 & 14.6 & 20.0 & 21.3 & 44.1 & 2.051 \\
\hline
\end{tabular}

Source: $w$ ww.trends.e-strategyblog.com 
Improving the Relationships between Organizations and their Customers Using Digital Multichannel Communication and Mathematical Simulation

The scores obtained for the characteristics for 2016 are $(3.19 ; 3.06 ; 2.582 ; 2.051)$, and their summing up is 10.883 . Thus, the vector line is becoming:(29.3\%; $28.1 \%$ $23.7 \% ; 18.9 \%)$.

The matrix formed by the values from 2015 will be multiplied with the line vector from 2016, according to Markov chains method:

$$
M=\left(\begin{array}{cccc}
52 & 26 & 9 & 13 \\
39 & 29 & 19 & 13 \\
20 & 27 & 35 & 18 \\
12 & 18 & 26 & 44
\end{array}\right) \times\left(\begin{array}{llll}
29.3 & 28.1 & 23.7 & 18.9
\end{array}\right)
$$

in order to observe the trend of the four analyzed variables of a website or the following years.

Using MATLAB program, we obtained the following results (Table 8).

For 2015 , the values are $(3.17 ; 2.94 ; 2.49 ; 1.98)$; summing these values we obtain 10.58; dividing each value to this sum we obtain the following results necessary for the table.

Table 8. The trend for the four analyzed variables of a website between 2015 and 2020

\begin{tabular}{|l|c|c|c|c|c|c|}
\hline Characteristics/year & $\begin{array}{c}\mathbf{2 0 1 5} \\
(\boldsymbol{\%})\end{array}$ & $\begin{array}{c}\mathbf{2 0 1 6} \\
(\boldsymbol{\%})\end{array}$ & $\begin{array}{c}\mathbf{2 0 1 7} \\
(\mathbf{\%})\end{array}$ & $\begin{array}{c}\mathbf{2 0 1 8} \\
(\mathbf{\%})\end{array}$ & $\begin{array}{c}\mathbf{2 0 1 9} \\
(\boldsymbol{\%})\end{array}$ & $\mathbf{2 0 2 0}$ \\
\hline Performance & 30.0 & 29.3 & 33.2 & 33.8 & 34.1 & 34.1 \\
\hline $\begin{array}{l}\text { Fresh and updated } \\
\text { content }\end{array}$ & 27.8 & 28.1 & 25.6 & 25.4 & 25.3 & 25.4 \\
\hline $\begin{array}{l}\text { Consistent } \\
\text { experience }\end{array}$ & 23.5 & 23.7 & 21.2 & 20.5 & 20.3 & 20.2 \\
\hline Personalized content & 18.7 & 18.9 & 20 & 20.3 & 20.3 & 20.3 \\
\hline
\end{tabular}

Source: Authors calculations using MATLAB.

These results are graphically represented to observe the trend of variables for the following period. 
Mircea Constantin Duica, Nicoleta Valentina Florea, Anisoara Duica, Raluca Gilmeanu

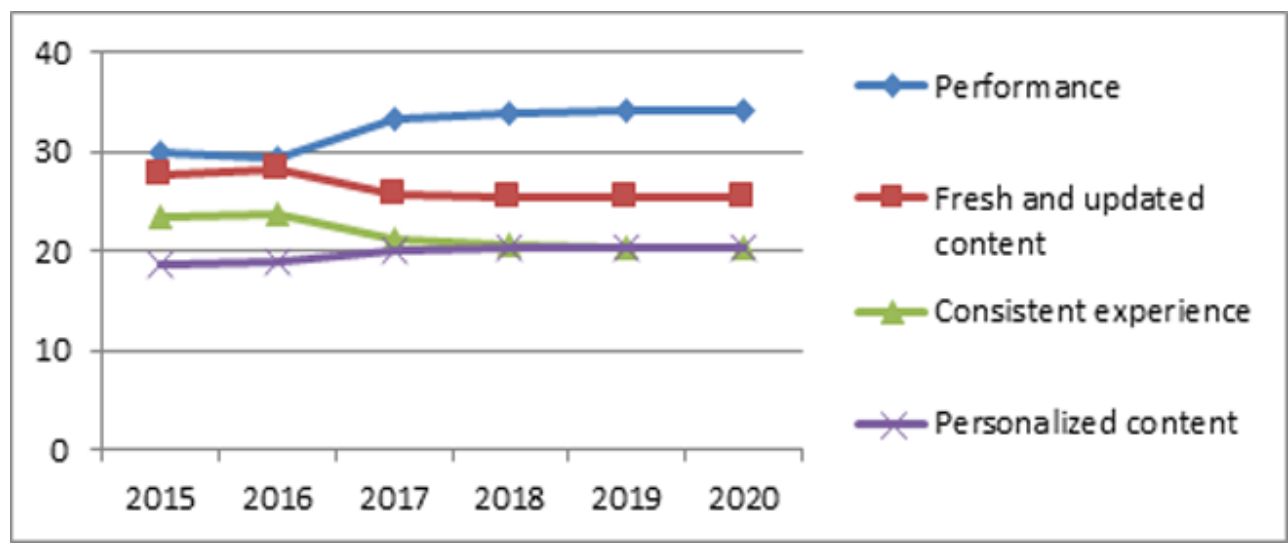

Figure 4. The trend of the four analyzed variables of a website (2015-2020).

We may observe that till 2020 (Figure 4) the performance and the personalization are the most wanted variables for an efficient website, while fresh and updated content and consistent experience are obtaining lower values due to the fact that from the habit of working with the computer, browsing the internet, using the website to order online, the current consumer is no longer so impressed by these variables as the beginning of the e-commerce period. Thus, the new econsumer is focusing on obtaining performance in a continuous changing and challenging environment and on personalized content, because the business is now made on-to-one, customized, not in mass as before.

\subsection{Analyzing the trend of social media tools frequency use}

According to statistics, Facebook is the most important social platform among B2C marketers, at great difference followed by Twitter (10\%), LinkedIn (9\%) and others (Table 9).

Table 9. Most important social channels (2015)

\begin{tabular}{|c|c|c|c|c|c|c|}
\hline Facebook & Twitter & LinkedIn & YouTube & Googlet & Pinterest & InstagramForums\& \\
\hline & & & & & & \begin{tabular}{|l|l} 
Social \\
review \\
sites
\end{tabular} \\
\hline $65 \%$ & $10 \%$ & $9 \%$ & $4 \%$ & $4 \%$ & $4 \%$ & $1 \%$ \\
\hline
\end{tabular}

Source:www.marketingcharts.com 
Improving the Relationships between Organizations and their Customers Using Digital Multichannel Communication and Mathematical Simulation

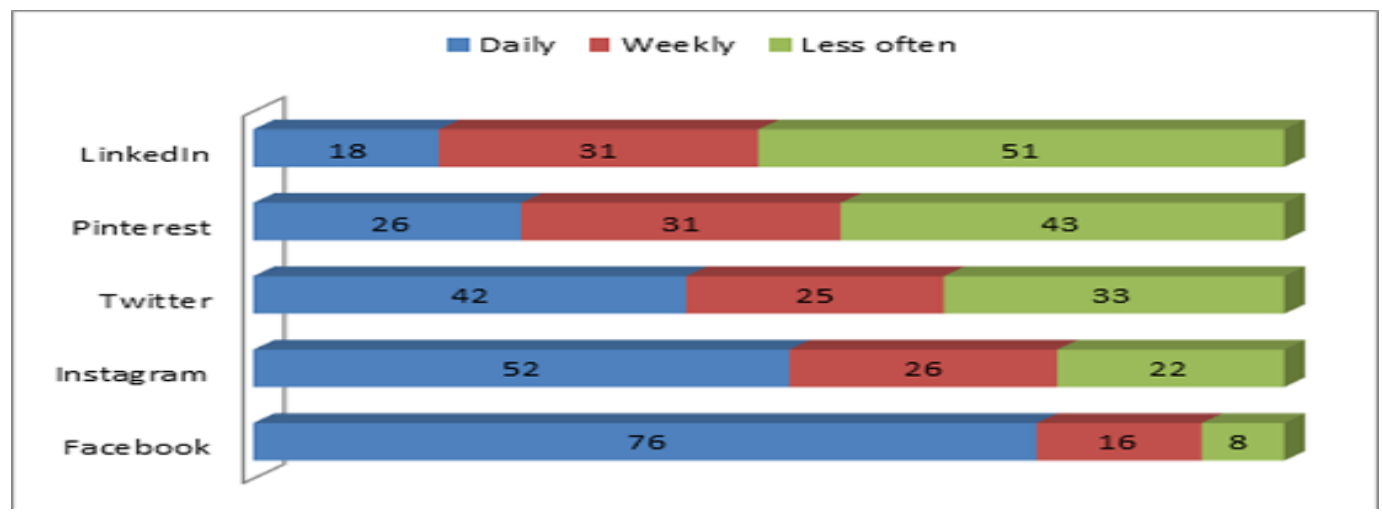

Figure 5. The use of social media platforms

Source: adaptation afterwww.trends.e-strategyblog.com/2016/12/03 and the authors calculation

Extracting data from the graphic above just for three social media tools are obtained the following data for each analyzed variable (Table 10).

Table 10. Frequency use of social media tools

\begin{tabular}{|l|l|l|l|}
\hline & Daily & Weakly & Less often \\
\hline Facebook & 76 & 16 & 8 \\
\hline Instagram & 52 & 26 & 22 \\
\hline Twitter & 42 & 25 & 33 \\
\hline
\end{tabular}

We made their summing up, then we transformed them into a line vector (Table $11)$.

Table 11. Data for three most important multichannel communication

\begin{tabular}{|l|l|l|l|}
\hline Facebook & Instagram & Twitter & Sum \\
\hline 65 & 3 & 10 & 78 \\
\hline
\end{tabular}

Making their wight from the total summing up, it is obtained:

Facebook- $65 / 78=0.83$

Instagram- $3 / 78=0.04$

Twitter-10/78 $=0.13$

Thus, the vector line is:

$\left(\begin{array}{lll}0.83 & 0.04 & 0.13\end{array}\right)$ 
Mircea Constantin Duica, Nicoleta Valentina Florea, Anisoara Duica, Raluca Gilmeanu

The values for frequency use we multiply them with the line vector, according to Markov chains theory. Thus, we obtain the trend for the next period for the three analyzed social tools.

$$
\left(\begin{array}{lll}
0.76 & 0.16 & 0.08 \\
0.52 & 0.26 & 0.22 \\
0.42 & 0.25 & 0.33
\end{array}\right) \times\left(\begin{array}{lll}
0.83 & 0.04 & 0.13
\end{array}\right)
$$

We obtain the following values for FIT, using Markov chains and MATLAB (Table 12).

Table 12. Trend of FIT using Markov chains

\begin{tabular}{|l|r|r|r|r|r|r|}
\hline $\begin{array}{l}\text { Trend of } \\
\text { SMT/year }\end{array}$ & $\mathbf{2 0 1 5}$ & $\mathbf{2 0 1 6}$ & $\mathbf{2 0 1 7}$ & $\mathbf{2 0 1 8}$ & $\mathbf{2 0 1 9}$ & $\mathbf{2 0 2 0}$ \\
\hline Facebook & 0,83 & 0,7062 & 0,677678 & 0,66923 & 0,666627 & 0,665821 \\
\hline Instagram & 0,04 & 0,1757 & 0,188199 & 0,190891 & 0,191678 & 0,19192 \\
\hline Twitter & 0,13 & 0,1181 & 0,134123 & 0,139879 & 0,141694 & 0,142259 \\
\hline
\end{tabular}

The graphical representation is made below, showing a different trend than the current values (Figure 6).

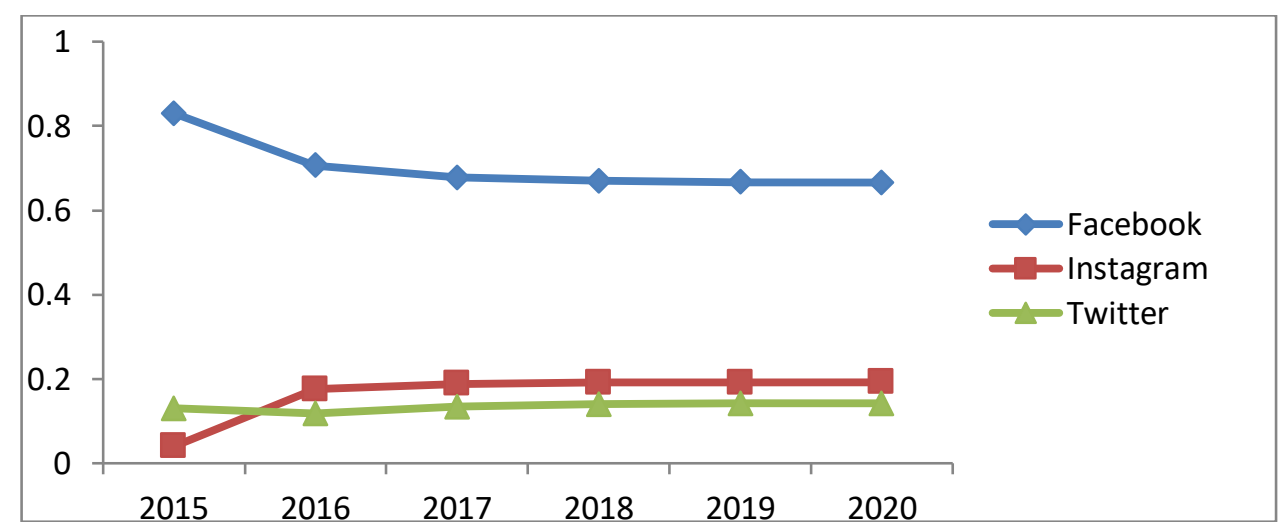

Figure 6. The graphical representation of future trend of FIT.

It may be observed for a simulated future, that the interest for Facebook (from $83 \%$ in 2015 to $66.58 \%$ in 2020 previsioned) is decreasing due to gaining interest in using Instagram (from $4 \%$ in 2015 to $19.19 \%$ in 2020 simulated), but still remaining the most used communication e-tool and for Twitter is registered just a small but positive increasing (from $13 \%$ in 2015 to $14.22 \%$ in 2020). 
Improving the Relationships between Organizations and their Customers Using Digital Multichannel Communication and Mathematical Simulation

\section{Conclusions}

Consumers needs are more and more challenging and in change performance organizations came with a new method of communication, more rapid, more efficient, and cheaper. If they do not receive added value, they will rapidly leave the social media provider. More and more consumer uses online activities: communication, finding a job, selling or buying online, banking, booking, and others; thus organizations are experiencing with new and expectations. To retain, attract and grow the number of e-customers, they must offer convenience, reduced costs, various products and services, good prices, good quality, good websites. Their offer must be at a click distance and think quicker then the competition. Thus, if the products are hard to see, or slowly, they will lose the customers. For that they must implement new programs using IT and communication systems such as social media, mobile activities, and ofcourse new simulation and modeling methods to see from time the trend of their future activities and the future risks.

\section{REFERENCES}

[1]Albright, R. (2018), Electronic Communication for the Home and Office; CRC Press, p.1;

[2]Baran, S.J., Davis, D.K. (2012), Mass Communication Theory. Foundations, Ferment, and Future, 6th Edition, Cengage Learning, MA, USA, p.37;

[3]Florea, N.V., Gilmeanu, R. (2016), Leadership Communication- An Efficient Way to Motivate Human Capital; Management \& Marketing, volume XIV, Issue, p.102;

[4]Florea, N.V., Mihai, D.C. (2015), Improving organization performance through human capital development, using a regression function and MATLAB, JOSA, No. 3(32), pp. 229-238;

[5]Gothelf, J., Seiden, J.(2017), Sense and Respond: How Successful Organizations Listen to Customers and Create New Products

Continuously, Harvard Business Review Press;

[6]Hynes, G.E., Veltsos, J.R. (2018). Managerial Communication: Strategies and Applications; SAGE Publications;

[7]Jain, A.K. et all. (2011), Professional Communication Skills, S.Chand\&Co.Ltd., ND, India, p.242;

[8]Janoshka A. (2013), Web advertising; Ph., USA, p.2;

[9]Jawadekar, W.S.(2004), Management Information Systems; Tata McGraw Hill Edu, India;

[10]Krizan, A.C., et al. (2011), Business Communication, 8th Edition, Cengage Learning, p. 9;

[11]Lowell, B., Joyce, C. (2007), Mobilizing Minds, McGrawHill; 
Mircea Constantin Duica, Nicoleta Valentina Florea, Anisoara Duica, Raluca Gilmeanu

[12]Natarajan, D.(2017),ISO 9001: Quality Management Systems; Springer, p.110;

[13]Neustaldter, C. et all. (2012), Connecting Families. The Impact of New Communication Technologies on Domestic Life; Springer, VA, USA, pp.2-3; [14]Thomas, A.R. et all.(2007), Direct Marketing in Action: Cutting Edge Strategies for Finding and Keeping the Best Customers; Praeger Pub., Westport, USA, p.5;

[15]www.adobe.com/2016, last accessed 23.11.2017;

[16]www.bluehornet.com/.../2015-Consumer-Views-of-Email-Marketing-2015, last accessed 10.02.2018;

[17]www.finance.yahoo.com/ last accessed 15.12.2017;

[18]www.forbes.com, last accessed 12.10.2017;

[19]www.internetlivestats.com/,last accessed 20.12.2017;

[20]www.internetworldstats.com, last accessed 15.06.2018;

[21]www.litmus.com/2016, last accessed 15.03.2018;

[22]www.marketingcharts.com,last accessed 15.12.2017;

[23]www.radicati.com/wp/wp-content/uploads/2017/01/Email-Statistics-Report2017-2021-Executive-Summary.pdf, last accessed 05.07.2018;

[24]www.statista.com, last accessed 15.12.2017;

[25]www.trends.e-strategyblog.com/2016,last accessed 01.07.2018. 